\title{
An evaluation of the potential for non-fortified foods to bear a micronutrient claim under EU regulations
}

\author{
S. M. Ní Bhriain ${ }^{1,2}$, E. M. Keaveney ${ }^{1}$, F. E. Douglas ${ }^{1}$, H. McNulty ${ }^{2}$ and M. A. T. Flynn ${ }^{1,2}$ \\ ${ }^{1}$ Public Health Nutrition, Food Safety Authority of Ireland, Dublin 1, Republic of Ireland and ${ }^{2}$ Northern Ireland Centre \\ for Food and Health, University of Ulster, Coleraine BT52 1SA, UK
}

As of February 2014,claims relating to micronutrients accounted for $68 \%$ (n171) of all authorised health claims(Article 13 and $14)^{(1)}$ under EU rules ${ }^{(2)}$. Such claims are only permitted on food ready for consumption which is at least a 'source of' the micronutrient. For solid and liquid foods, this means the food must provide a minimum amount of the relevant micronutrient equivalent to $15 \%$ of the labelled daily reference intake per $100 \mathrm{~g}$ and $100 \mathrm{ml}$ respectively, and $7 \cdot 5 \%$ per $100 \mathrm{ml}$ for beverages ${ }^{(3)}$. This study aims to evaluate the potential for non-fortified foods to bear a micronutrient claim under current legislation.

For this study food items (n2928) from the Composition of Foods integrated dataset (CoF IDS) ${ }^{(4)}$ were re-categorised according to the food groups in Ireland's Healthy Eating Guidelines ${ }^{(5)}$. A food item was excluded if it was a composite dish (n810), not in a ready-to-eat state ( $n 416)$, appeared more than once in the database $(n 181)$, or a fortified food ( $n 33)$, resulting in 1488 foods included in the current analysis. To assess the potential of each food to bear a micronutrient claim, the nutritional composition of the food was compared against the minimum value required to meet the 'source of' that micronutrient (i.e. $15 \%$ of the labelled daily reference intake per $100 \mathrm{~g} / 100 \mathrm{ml})$.

\begin{tabular}{|c|c|c|c|}
\hline \multirow[b]{2}{*}{ Food Group (n) } & \multicolumn{3}{|c|}{$\begin{array}{l}\text { Proportion (\%) of foods permitted to bear a } \\
\text { micronutrient claim }\end{array}$} \\
\hline & $\begin{array}{c}\text { Vitamin \& mineral } \\
\text { claim } \\
\text { median } \\
\text { (range) }\end{array}$ & $\begin{array}{l}\text { Vitamin } \\
\text { claim } \\
\text { median } \\
\text { (range) }\end{array}$ & $\begin{array}{l}\text { Mineral } \\
\text { claim } \\
\text { median } \\
\text { (range) }\end{array}$ \\
\hline $\begin{array}{l}\text { Cereals, breads \& } \\
\text { potatoes group (128) }\end{array}$ & $14(0-59)$ & $7(0-51)$ & $22(5-59)$ \\
\hline $\begin{array}{l}\text { Fruit, vegetables \& } \\
\text { salads group (404) }\end{array}$ & $4(0-48)$ & $3(0-48)$ & $7(0-29)$ \\
\hline $\begin{array}{l}\text { Milk, yoghurt \& cheese } \\
\text { group (80) }\end{array}$ & $6(0-81)$ & $2(0-74)$ & $24(0-81)$ \\
\hline $\begin{array}{l}\text { Meat, fish \& } \\
\text { alternatives group (621) }\end{array}$ & $26(2-75)$ & $13(2-67)$ & $28(3-75)$ \\
\hline $\begin{array}{l}\text { Fats, oils \& spreads } \\
\text { group }(53)\end{array}$ & $0(0-53)$ & $0(0-53)$ & $0(0-18)$ \\
\hline $\begin{array}{l}\text { Confectionary, biscuits } \\
\& \text { crisps group (202) }\end{array}$ & $10(1-49)$ & $9(1-19)$ & $15(2-49)$ \\
\hline
\end{tabular}

The table outlines the median proportion and range (minimum and maximum) of foods in each food group which would be permitted under current legislation to bear one or more micronutrient claims. The results showed that fewer claims would be permitted relating to vitamins compared with minerals. The foods in the meat group would be permitted to bear the most claims with over a quarter providing the minimum value required to meet the 'source of' a micronutrient. Foods in the fats group, followed by foods in the fruit and vegetables group would be permitted to bear the least number of micronutrient claims. Foods in the fruit and vegetables group and the milk group, which are promoted for healthy eating, compare unfavourably to those within the confectionary group, the consumption of which should to be limited, in terms of the proportion of foods that would be permitted to bear a claim. The micronutrients for which foods in all food groups would be permitted to bear the most claims relating to are phosphorous (40\%), zinc $(36 \%)$, potassium $(35 \%)$, vitamin $\mathrm{B}_{12}(33 \%)$ and chloride $(33 \%)$ whereas the least number of claims would be permitted relating to biotin $(6 \%)$ and vitamin $\mathrm{D}(7 \%)$.

In conclusion, the results show a relatively low proportion of non-fortified foods would be permitted to bear claims under current legislation. Nutrient profiles are urgently required to ensure that foods considered to have unhealthy nutrient profiles would not be permitted to bear claims.

1. EU Register on Nutrition and Health Claims.http://ec.europa.eu/nuhclaims/(accessed February 2014).

2. Regulation (EC) 1924/2006 on nutrition and health claims made on food.

3. Regulation (EU) $1169 / 2011$ on the provision of food information to consumers

4. Food Standards Agency (2002) McCance and Widdowson's The Composition of Foods integrated dataset (CoF IDS). http://www.food.gov.uk/ science/dietarysurveys/dietsurveys/ (accessed November 2013).

5. Food Safety Authority of Ireland (2011). Scientific Recommendations for Healthy Eating Guidelines in Ireland. Dublin: FSAI. 